\title{
Search and Retrieval in Seventeenth-Century Manuscripts: The Case of Joseph Hall's Miscellany
}

\author{
Angus Vine
}

\begin{abstract}
One of the challenges faced by compilers of early modern miscellanies was how to find material after it had been copied. In this essay, Angus Vine explores schemes for search and retrieval, from incipient indices to tipped-in texts, using as a case study the meticulously planned miscellany later owned by Joseph Hall. The original compiler of this manuscript collected a wide range of material, including theological texts, scientific and medical items, political reports and other news, and large amounts of verse. He devised a system of seven categories, dividing his manuscript into sections. The essay examines the compiler's classificatory system, what actually happened when he and another scribe started to copy material, and what this says about how early modern miscellanies were used. KEY WO RDs: Henry Oxinden; John Payne Collier; categories in early modern miscellanies; strategies for manuscript compilation; concepts of generic organization; taxonomy; manuscript mise-en-page
\end{abstract}

IN 1673, in the Supplément des traitez de la connoissance des bons livres, the French author and historiographer royal Charles Sorel warned of the dangers of overabundant and disordered notes:

What a strange misfortune is it to have so many goods that, not knowing which to use, one uses none at all. [...] Some will say that abundance is always better than dearth and that if everything one has amassed and offers up is of great value, it is always pleasant; nonetheless extravagant and irrelevant items should never be valued. ${ }^{1}$

1. Charles Sorel, Supplément des traitez de la connoissance des bons livres, in De la connoissance des bons livres: ou, examen de plusieurs autheurs, ed. Hervé D. Béchade (Geneva, 1981), 7: "Voila un étrange

Pp. 325-343. ( 2017 by Henry E. Huntington Library and Art Gallery. ISSN 0018-7895 | E-ISSN 1544-399x. All rights reserved. For permission to photocopy or reproduce article content, consult the University of Pennsylvania Press Rights and Permissions website, http://www.upenn.edu/pennpress/about/permissions.html. 
Sorel's warning registers a double danger: on the one hand, the kind of information overload that resulted in stasis and masses of unused material; and on the other, the verbiage, prolixity, and empty displays of learning that ample notebooks often encouraged, and about which seventeenth-century writers and scholars, especially those associated with the new philosophies, were increasingly critical. Implicitly, his warning also points to a third problem: the difficulty of searching for and retrieving items already noted. If individuals compiled too much material, no matter how good it was, they would struggle to find what they wanted in the future. For notes to be truly useful, they had to be organized, and for Sorel that meant that they also had to be selective. Judgment was required: the compiler needed to excise any "extravagant" items or material "irrelevant" to his or her purpose.

Sorel's warning echoes a set of widespread concerns in early modern learned discourse about the proliferation of information and books. Those concerns, which arose in part from the sense that the rapid accumulation of books over the course of the sixteenth century had disabled the pursuit of knowledge as much as it had enabled it, are familiar to scholars and have been the subject of several penetrating studies-most notably, Ann Blair's Too Much to Know. ${ }^{2}$ What is less familiar is the way in which those concerns affected manuscript culture. Yet Sorel's observation, commenting as it does on reading notes, is directed primarily at compilers of manuscript books rather than printed ones. Furthermore, the problem of information management that Blair so brilliantly documents in relation to print was equally an issue for manuscript culture. Just as print generated a series of organizational schemes that allowed readers easy and quick access to specific pieces of information, so compilers of manuscript miscellanies devised strategies to enable the kind of search and retrieval that would make their collections useful as well as voluminous, and thus escape the dangers of which Sorel and other theorists of reading warned. Although the schemes in printed books have been systematically studied, their manuscript counterparts, which range from marginal symbols to tabs and tipped-in slips, have received rather less attention. ${ }^{3}$ This essay,

mal-heur d'avoir quelquefois tant de Biens, que ne sçachant desquels il se faut servir, on ne s'en sert point du tout. [...] On dira que l'Abondance vaut toûjours mieux que la Disette, \& que si tout ce qu'on a est de grand prix, quelque chose qu'on ait amassé \& quelque chose qu'on debite, cela sera toûjours agreable; Neantmoins les choses extravagantes \& hors de propos ne sont jamais gueres à estimer"; quoted and translated in Ann M. Blair, Too Much to Know: Managing Scholarly Information before the Modern Age (New Haven, Conn., 2010), 89-90.

2. See also Kathryn Murphy, “The Anxiety of Variety: Knowledge and Experience in Montaigne, Burton, and Bacon," in Fictions of Knowledge: Fact, Evidence, Doubt, ed. Yota Batsaki, Subha Mukherji, and Jan-Melissa Schramm (Basingstoke, U.K., 2011), 110-30; and Murphy, "Robert Burton and the Problems of Polymathy," in "The Copious Text: Encyclopaedic Books in Early Modern England," ed. Abigail Shinn and Angus Vine, special issue, Renaissance Studies 28 (2014): 279-97.

3. The study of slips is a notable exception and has become an emerging subfield in the histories of information and knowledge; see Noel Malcolm, "Thomas Harrison and His 'Ark of Studies': An Episode in the History of the Organization of Knowledge," The Seventeenth Century 19 (2004): 196-232; and Blair, Too Much, 93-102. For the history of slips more generally, see Edward Tenner, "From Slip to Chip: How Evolving Techniques of Information Gathering, Storage, and Retrieval Have Shaped the Way We Do Mental Work," Microform Review 21 (1992): 123-27. 
which sets out to explore those strategies and uncover some of the motivations and ways in which compilers organized their manuscript books, is therefore an attempt to redress some of that imbalance.

There is another reason for focusing on strategies for search and retrieval in this way. By examining these organizational schemes, this essay emphasizes how miscellanists and note-takers used, and continued to use, manuscript books after their initial compilation. Notebooks and miscellanies were not only passive repositories of texts but also frequently cues for action. Much of the material copied in them-recipes (culinary, medical, and equine), legal and household records, formularies, and accounts-constituted practical knowledge, gathered for some putative future use. For that material to be truly useful, it had to be organized and retrievable. This kind of nonliterary material is, for understandable reasons, less familiar to scholars than the poetry, political gossip, and news also found in miscellanies, and yet it is just as important a part of early modern manuscript culture. Focusing on miscellanies in this way, therefore, restores attention not only to an understudied element in the histories of knowledge and information but also to an under-researched aspect of manuscript studies. Miscellanies were dynamic and transformative rather than finite or finished artifacts. 4 Their compilers typically acquired the kinds of texts and knowledge discussed in this essay at various times and from various places, and thus copied them discontinuously and nonconsecutively. And that required organizational schemes and finding devices.

This essay takes one manuscript in particular as a case study: the volume known today (somewhat misleadingly) as Joseph Hall's miscellany. 5 This manuscript, first compiled in the 1630 s and 1640 s, is an octavo paper-book $(5.75 \times 4$ in.; $146 \times 100 \mathrm{~mm})$, originally of three hundred leaves, although nine are now missing, in quires of eight and four. Although the volume was rebound in the twentieth century, traces of its original reddish-brown calf binding are preserved at its sides, and it is certainly possible that the original compiler acquired it as a bound book. ${ }^{6}$ What is certain is that, having acquired the paper-book, and before entering anything into it, the compiler thought carefully about both the kind of material that he might copy and, perhaps more importantly, where he would copy it. Those decisions guided the spatial disposition of the

4. See further Jonathan Gibson, "Synchrony and Process: Editing Manuscript Miscellanies," SEL 52 (2012): 85-100.

5. MS V.a.339, Folger Shakespeare Library, cited hereafter in the text. The attribution to Hall is based solely on the signature "Joseph Hall" on one of the front flyleaves. There is nothing else in the manuscript in this hand, suggesting that this Joseph Hall-not, alas, the bishop of Norwich and satirist-was a later owner of the volume rather than one of its original compilers. The manuscript was, however, attributed to Hall in the nineteenth century (see, for example, A Catalogue of Shakespeareana, comp. F. A. Wheeler, 2 vols. [London, 1899], no. 386), and the name has now stuck. The manuscript is therefore referred to as Joseph Hall's miscellany in the Folger's card catalogue and Hamnet online catalogue.

6. A typescript note, inserted after the volume was rebound at the Folger bindery, suggests the same thing: "Before it was taken apart and rebound (by R. Lunow) this MS was in a binding of the early 17 th century, the sides of which are here preserved. It was bound before the first owner (Joseph Hall?) acquired it as a blank book about 1630 and had not been rebound." 
notes that he subsequently took and thus also the overall organization of the book. Although the arrangement of material in the manuscript is more complex and more precise than is often the case in surviving miscellanies, the underlying organizing principle and the strategies for search and retrieval are entirely typical. By taking Hall's manuscript as a case study, this essay can therefore offer a contribution toward a typology of how miscellanists in the seventeenth century used (and, more importantly, reused) their manuscript books. That, in turn, enables it to shed light on the manuscript identities with which this issue as a whole is concerned.

\section{宛}

The presence of organizing strategies and finding devices in notebooks and miscellanies suggests the fundamentally memorial nature of much of what was copied into them. Classical writers understood notes (notas) as cues to the memory, and that sense continued in the medieval and early modern periods. Quintilian, for example, in his Institutio oratoria, recommended that, when "things do not stick easily in the mind, it is quite useful to attach some marks to them, the recall of which will warn and jog the memory." "No one," he added, "will be so ill-endowed as not to remember what symbol he has assigned to any given passage."7 Quintilian's notes are therefore metaphorical rather than literal marks: cues that are not necessarily written down or vocalized, but that enable an orator to recall a long speech. In the postclassical world, however, notes were increasingly understood as actual marks on the page, and their mnemonic function, as Mary Carruthers has shown, was frequently linked to mise-en-page and other distinctive features of layout. ${ }^{8}$ As the twelfth-century canon Hugh of Saint-Victor argued in one of the best-known medieval treatises on memory:

Therefore it is a great value for fixing a memory-image that when we read books, we study to impress on our memory through our mentalimage-forming power not only the number and order of verses or ideas, but at the same time the color, shape, position, and placement of the letters, where we have seen this or that written, in what part, in what location (at the top, the middle, or the bottom) we saw it positioned, in what color we observed the trace of the letter or the ornamented surface of the parchment.9

7. Quintilian, The Orator's Education, ed. and trans. Donald A. Russell, 5 vols., Loeb Classical Library 494 (Cambridge, Mass., 2001), 11.2.28-29: "non est inutile, iis quae difficillimus haereant aliquas apponere notas, quarum recordatio commoneat et quasi excitet memoriam; nemo etiam fere tam infelix, ut, quod cuique loco signum destinaverit, nesciat."

8. Mary Carruthers, The Book of Memory: A Study of Memory in Medieval Culture (Cambridge, 1990), 92-94.

9. Hugh of Saint-Victor, "De tribus maximis circumstantiis gestorum"; quoted in Carruthers, The Book of Memory, 261-66 at 264. See also Grover A. Zinn Jr., "Hugh of Saint Victor and the Art of Memory," Viator 5 (1974): 211-34. 
Hugh's point is that a distinctive manuscript page acts as a mnemonic aid because its visual features impress on the memory more easily than words alone, and thus also make any subsequent recall of the words on that page an easier process. "Nothing," he concluded, is "so useful for stimulating the memory as this."

Many of the strategies for search and retrieval found in early modern miscellanies suggest that a similar sense persisted into the sixteenth and seventeenth centuries. Whereas Hugh's concern is with students memorizing passages from other authors, and is thus a direct descendant of the classical arts of memory, the strategies in miscellanies act as cues to themselves as well as to other bodies of knowledge. Early modern examples of the spatial organization of manuscript books and their materialization of memory range from the widespread to the highly particular, from humanist commonplace books - whose heads, copied at the top of each leaf, provide a ready-made finding device-to the elaborate and idiosyncratic books of remembrance of Elizabeth Isham. ${ }^{10}$ In both instances, though, mise-en-page is the key to mnemonic function. With commonplace books, compilers only had to turn to a leaf with a particular head on it to find a supply of material on that topic. Heads thus operate as an index not only to the commonplace book itself but also to the knowledge gleaned by the compiler from his or her reading. Furthermore, the layout was crucial here; before collecting any material, compilers would usually rule the pages of their books with three lines each, to create narrow compartments into which they would copy their heads or topics and larger spaces for the commonplaces themselves. Isham's manuscripts, too, use compartments to organize and store information, and in her case, as Margaret Ezell has argued, they explicitly represent ongoing attempts to counter the fallibility of the internal memory with external, textual memories. ${ }^{11}$

Another way in which compilers of miscellanies drew on the material potential of books as a mnemonic aid was through the use of tabs and tipped-in slips. Henry Oxinden, the Kentish gentleman and poet, was one such compiler. ${ }^{12}$ Oxinden cut out scraps of paper, which he later pasted in to blank pages of his miscellanies. On these he copied items of particular importance to him. One such example is the cure for coughing, which he wrote on the verso of a small scrap of printer's waste and then glued, at one end only, onto a blank page of the miscellany that he kept from the 1640 os through to his death in 1670.13 The miscellany contains more than thirty cures for coughs and colds; the fact that this recipe alone is tipped in in this way suggests that Oxinden

10. The best introduction to commonplace books remains Peter Beal, "Notions in Garrison: The Seventeenth-Century Commonplace Book," in New Ways of Looking at Old Texts: Papers of the Renaissance English Text Society, ed. W. Speed Hill (Binghamton, N.Y., 1993), 131-47. For Isham's manuscripts, see Margaret J. M. Ezell, “Elizabeth Isham’s Books of Remembrance and Forgetting," Modern Philology 109 (2011): 71-84.

11. Ezell, "Elizabeth Isham's Books," 84.

12. For more on Oxinden, see Oxford Dictionary of National Biography, s.v. "Oxinden [Oxenden], Henry (1609-1670)," by Sheila Hingley, last modified 2004, doi: 10.1093/ref:odnb/21053.

13. Folger, MS V.b.110, fol. [13]v: "Take a quarter of a pint of water out of the Beares Mouth at Cripple gate, \& slice A halfe penny worth of liquorise \& an ounce of white sugar candie, \& let it ly all night in the water \& drink it off in the morning." 
wanted it to be easily retrievable, perhaps because it was a more effective remedy than some of the others. ${ }^{14}$ This method suggests that he shared the medieval sense of the mnemonic value of mise-en-page, using the physical space of a material book as a cue to his memory. But he did not necessarily share the pedagogical assumptions that lay behind the prescriptions of writers such as Hugh. Oxinden's tab operates instead in a manner akin to a turned-down page or modern bookmark. Furthermore, as the tab stands proud of the page, it would have served as a particularly efficient and easily noticeable attention-getter for an individual piece of information.

Strategies for search and retrieval were not always as obvious as heads, tabs, or tipped-in slips. Hall's miscellany is a case in point. Its compiler, too, used the physical space of the manuscript as a finding device, and yet, unlike in commonplace books, the underlying structure and organizing principle are not immediately apparent. Indeed, this miscellany is, on the face of it, chaotic and disordered. It seems to subscribe to little in the way of an overarching structure. Its contents are bewilderingly diverse, ranging from poems, sermon-notes, and prayers to notes on angling, medical recipes, and copious sets of instructions, from guides to how "to make Birdlime" to recipes for "red sealing waxe" and "good black inke" (fols. 182v-84r). There are also a number of magic tricks, including an astonishing set of instructions titled "A Capon to bringe foorth chickinges" (fol. 184r) - apparently the key to this biological marvel was to tickle the capon's belly with nettles. Also noted are formularies, a list of rhetorical tropes and schemes, political items, and various pieces of news, but as was often the case with news in miscellanies, what was copied was not in fact particularly new. ${ }^{15}$ The impression of disorder is exacerbated by the appearance of the pages themselves: by the sheer volume of items copied on them and the density of the notes (fig. 1).

Nonetheless, the miscellany is not quite the mess that it appears to be. For one thing, originally the manuscript was not as densely filled in as it is today. Indeed, until the mid-nineteenth century, when it had the misfortune to pass through the hands of the Victorian critic and forger John Payne Collier, there were a number of blank leaves in it. Collier, however, took advantage of this space to copy a series of eighty-three ballads in his own version of an early modern secretary hand, seemingly in an attempt to authenticate some of his other forgeries. ${ }^{16}$ Collier's ballads are unfortunate for all sorts

14. Most of the other recipes are at fols. [6]v-[9]r, grouped under such headings as "These ar for a Cough," "For a Cold: \& a Cough," "Against consumption," and "For an old cold or disication." Individual recipes here would have been much harder to find than the tipped-in remedy, although Oxinden did pick out four of them at fol. [7]v with black manicules in the margin. For the use of manicules, see William H. Sherman, Used Books: Marking Readers in Renaissance England (Philadelphia, 2008), 25-53.

15. The capon trick seems to have had some currency at the time: for a longer, but also more prosaic set of instructions, see Folger, MS V.a.140, fol. [16]v. For the copying of news into notebooks and miscellanies, see Joad Raymond, "Irrational, Impractical and Unprofitable: Reading the News in Seventeenth-Century England," in Reading, Society, and Politics in Early Modern England, ed. Kevin M. Sharpe and Steven N. Zwicker (Cambridge, 2003), 185-212 at 195.

16. Giles E. Dawson, “John Payne Collier's Great Forgery," Studies in Bibliography 24 (1971): 1-26; Arthur Freeman and Janet Ing Freeman, John Payne Collier: Scholarship and Forgery in the Nineteenth Century, 2 vols. (New Haven, Conn., 2004), 1:502-14. 
of reasons, not least the fact that they give the impression that the manuscript is both more copious and more disordered than it originally was. Collier copied his ballads wherever he could find blank space. Before he got hold of the manuscript, folios $39 \mathrm{v}-41 \mathrm{r}, 107 \mathrm{v}-79 \mathrm{r}, 181 \mathrm{v}, 228 \mathrm{v}, 243 \mathrm{r}-46 \mathrm{r}$, and $276 \mathrm{v}-77 \mathrm{r}$ were entirely blank, and the lower halves of folios 39r, 181r, and 227r were also empty. By the time that he had finished, only two of these (fols. 276v-77r) remained blank.

By filling up blank space in this way, Collier's ballads also distort the careful disposition of material devised by the original compiler. For despite appearances, and for all the diversity of its content, the manuscript is not disordered. The original compiler, before copying anything, allotted various parts of the book to various kinds of material. The compiler's identity is unknown, but he is the first of the two scribes who copied the majority of the items (apart from the ballads). Both scribes wrote in a secretary hand, and their work is neat, careful, and compact. (That they wrote secretary suggests that they were men; women tended to use mixed italic and roman hands. ${ }^{17}$ However, their hands are clearly different and can be securely distinguished (fig. 2). The hand of the first scribe (Hand A), who entered the majority of items on the page reproduced here (fol. 185v), is smaller, more formal, and more upright, whereas the hand of the second scribe (Hand B), who entered the two items at the bottom of the page between the horizontal lines, is larger and slightly more cursive. This distinction is also supported by the forms of individual graphs, with miniscule $g$ serving as a particularly useful diagnostic tool. Whereas the $g$ of Hand A is twin-bowled, with a lower compartment that stretches to the right, the graph of Hand $B$ does not have a lower bowl, but a tail that loops to the left instead. Majuscule $A$ provides a further, if slightly less reliable, diagnostic tool: whereas Hand A's graph resembles the italic form of the letter, Hand B tends to prefer the Anglicana form, with an upper lobe above the main bowl.

The evidence that Hand A was the original compiler, and thus also the deviser of the organizing principle and classificatory scheme, comes from the beginning of the manuscript. The first item, a shape poem on the sun (fol. 2r), is in Hand A. So too are most of the next twenty-five items, which revealingly are copied as a single text block. It is, of course, possible that the two scribes worked coterminously. Their entries do sometimes overlap. As shown in figure 2, Hand B added his two items ("To take fishe" and "to make Inke") at the foot of a list compiled by Hand A, but at the top of the next page (fol. 186r), Hand A resumes. In the same way, at the beginning of the manuscript, Hand B did enter the odd item alongside and sometimes even within Hand A's text block: on the verso of the shape poem, for example, he took reading notes from the theologian Dr. Thomas Playfere ("Playfere in verba Evangelistæ" [fol. 2v]). However, given the personal nature of the miscellany, and the sometimes conflicting sense of the entries, it seems more likely that the two scribes worked independently and consecutively. In the two instances above, therefore, Hand B probably copied the items where he did simply because there was still space there.

17. For more on the differences between men's and women's hands, see Heather Wolfe, "Women's Handwriting," in The Cambridge Companion to Early Modern Women's Writing, ed. Laura Lunger Knoppers (Cambridge, 2009), 21-39. 


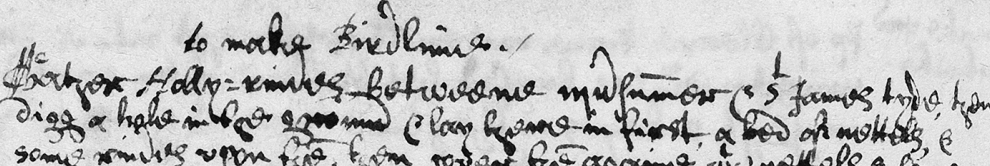

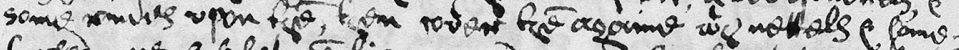

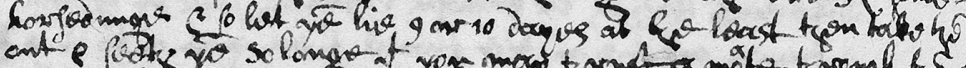

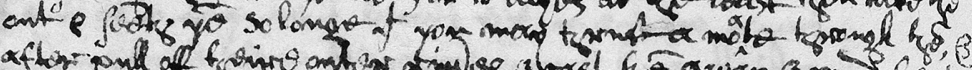

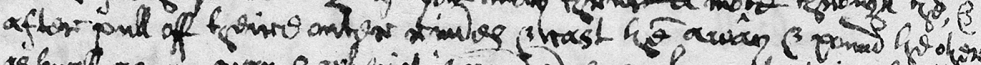

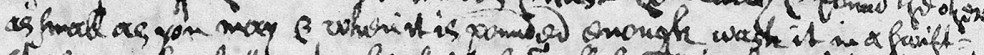

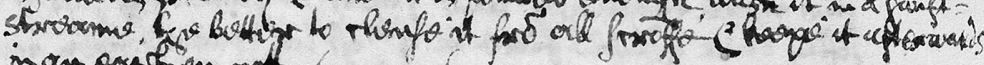
inar counfion not.

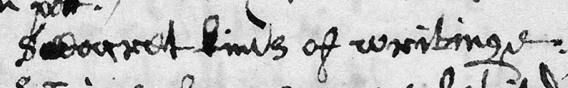

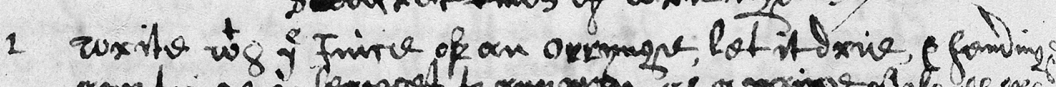

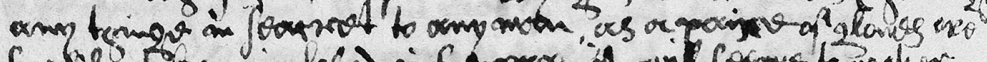

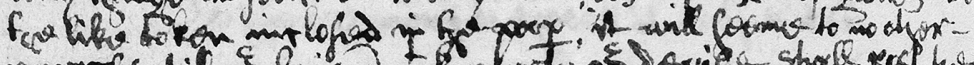

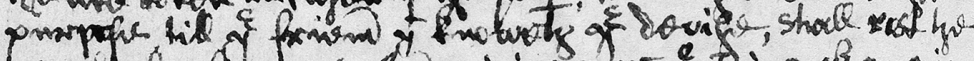

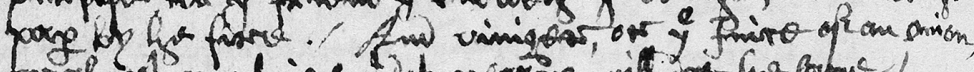

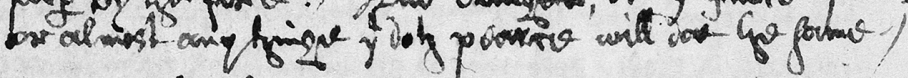

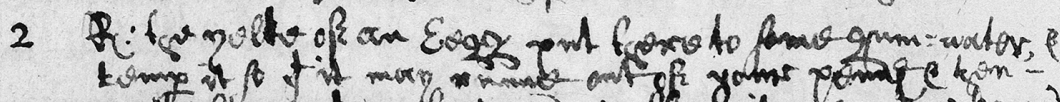

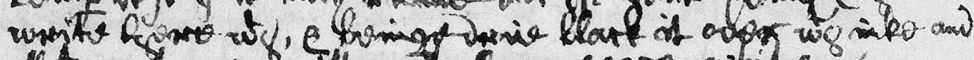

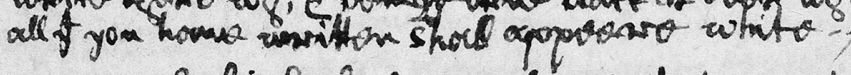

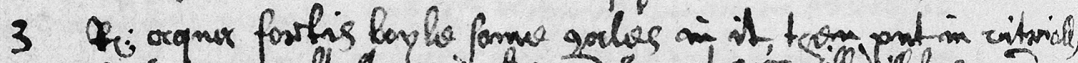

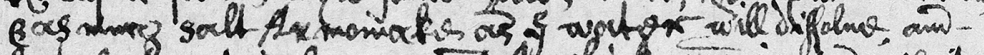

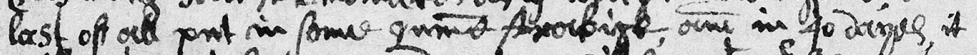

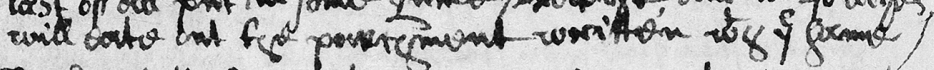

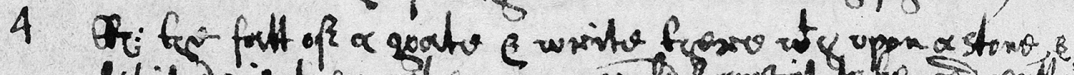

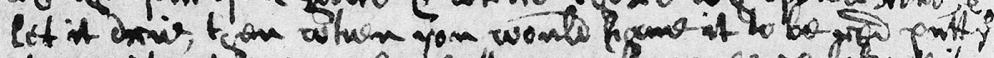
stome nito vimigose \& fel lethass wall appoconte like ds it

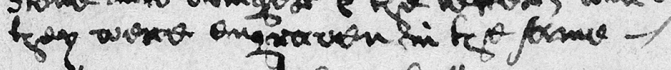

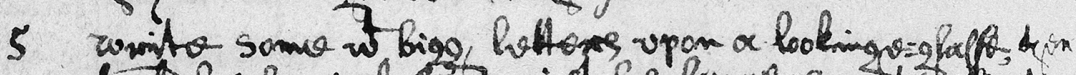

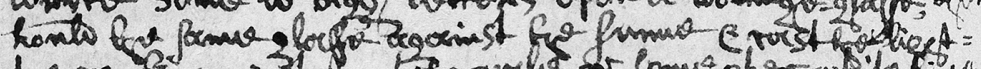

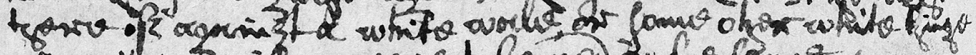

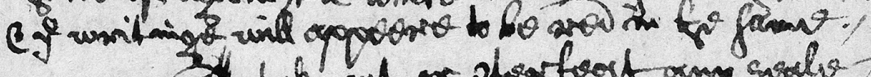

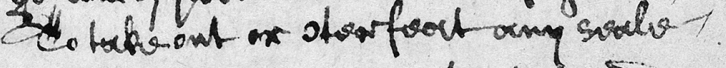

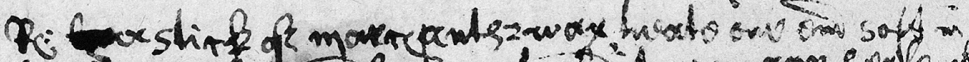

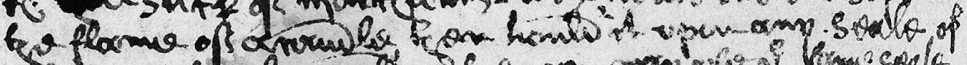

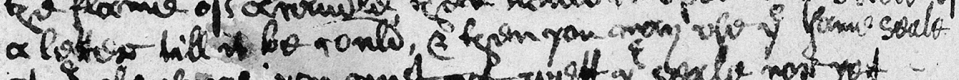

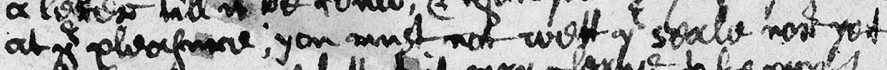

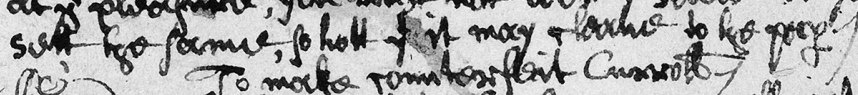

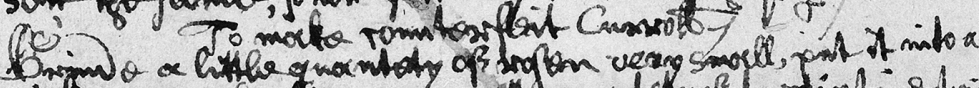

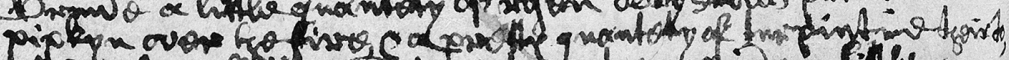

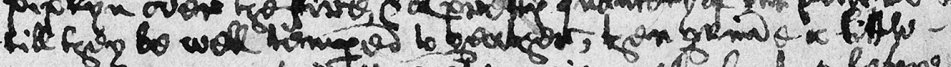

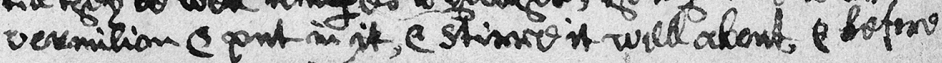

FIGURE 1. Joseph Hall's miscellany. MS V.a.339, Folger Shakespeare Library, fols. 182v-83r. By permission of the Folger Shakespeare Library. 


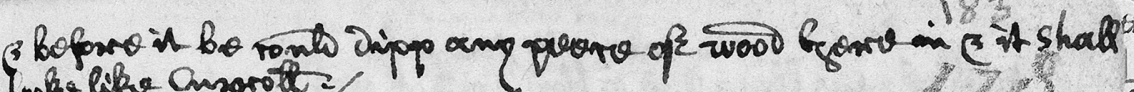

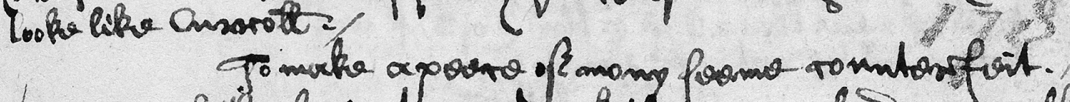

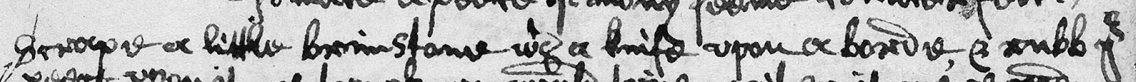

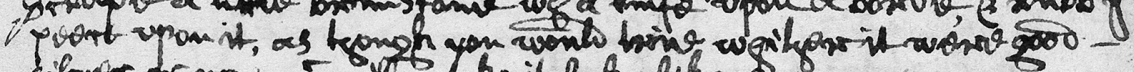
silve do na, w will mate it looke likg copagoor.

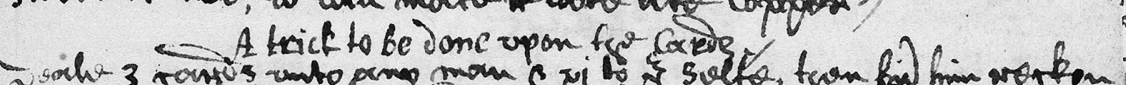

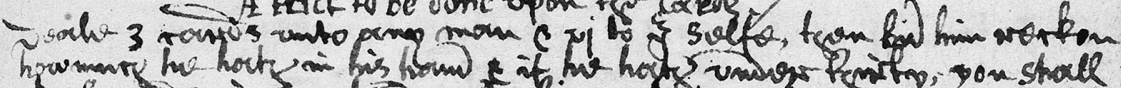

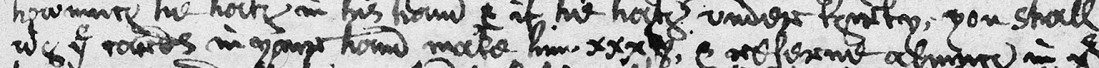

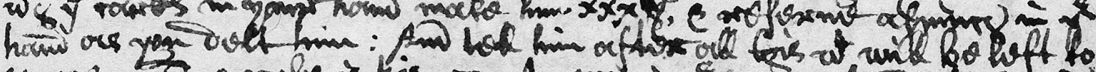

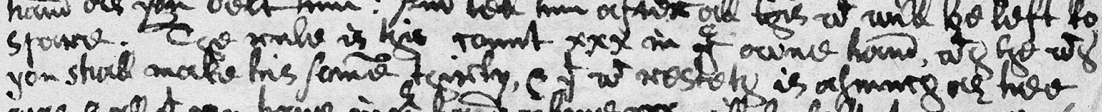

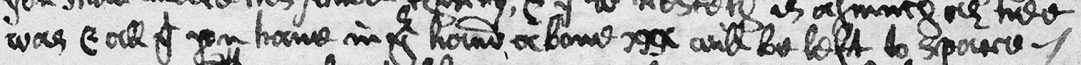

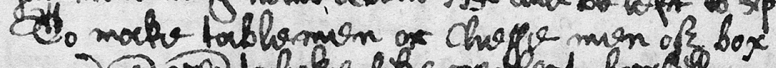

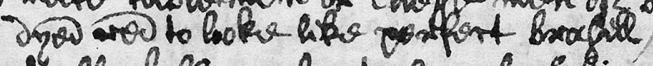

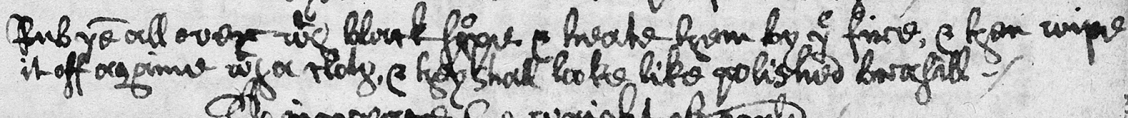

Do inmerto fer wonight of gonts.

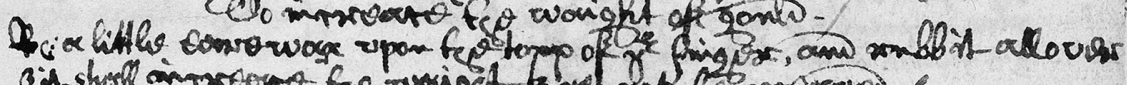
Bit sheth an

el. hom a gov liget by rom lohiget.

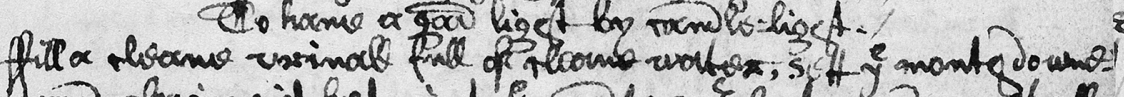
hame a voning atheno higet.

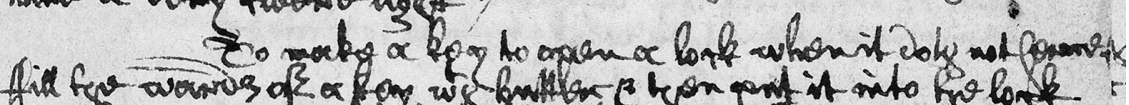

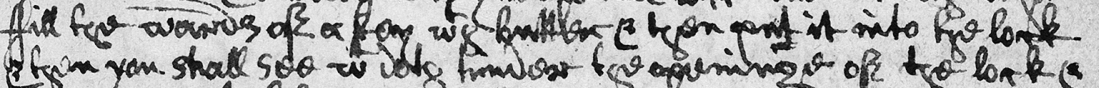
Fent yom mons fille ocworm. co make ach ingo fermo to burmo

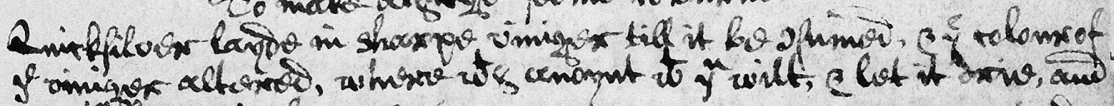

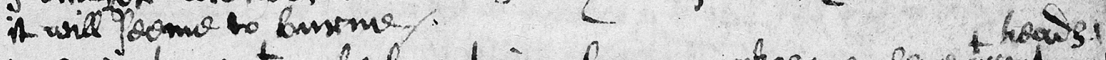

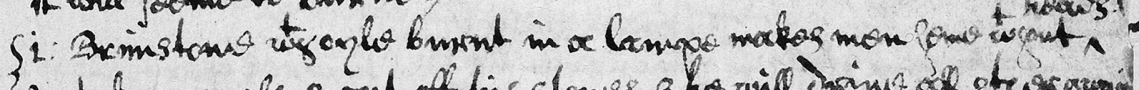

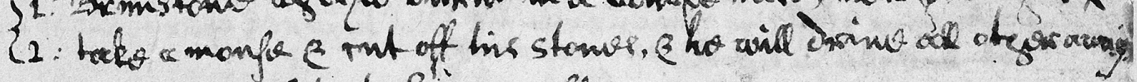

hokjo nunge?

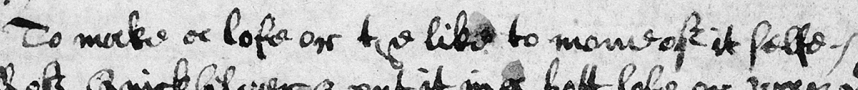

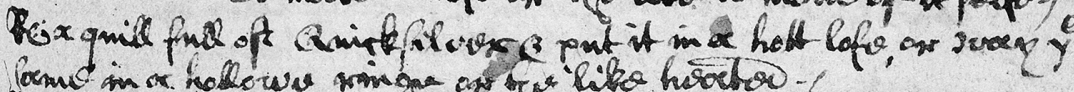

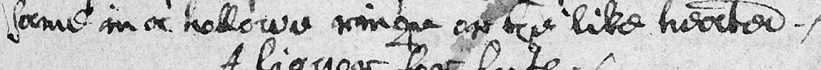

$$
\text { Alignow for boots. }
$$

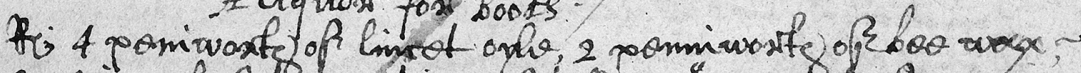

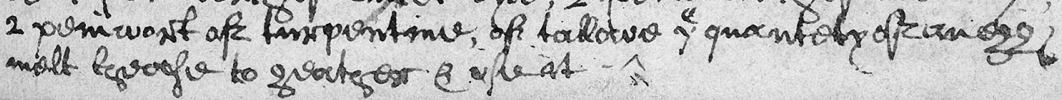




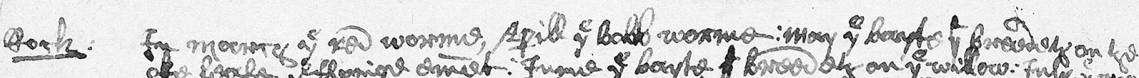

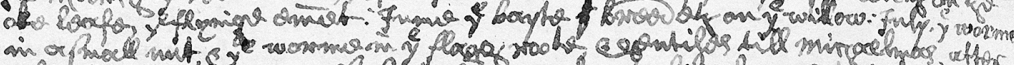

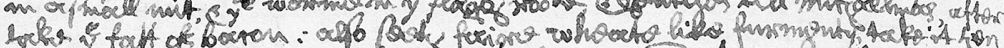

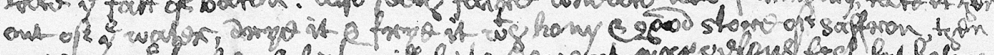

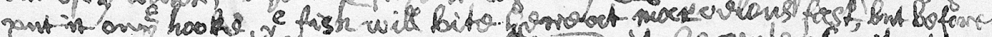

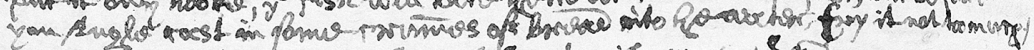

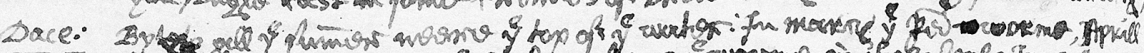

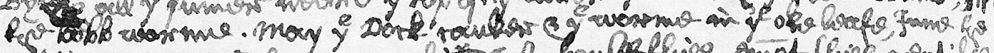

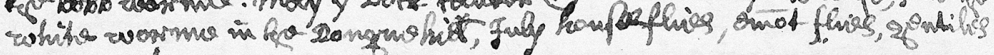

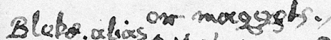

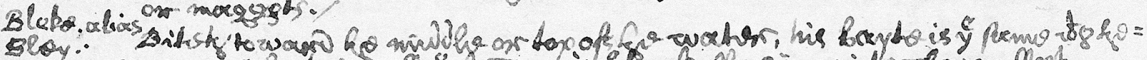

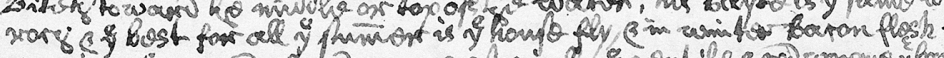

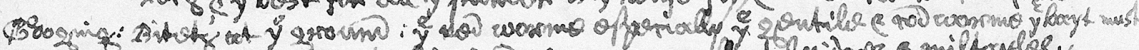

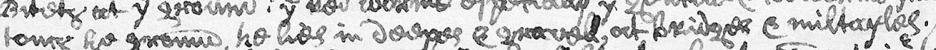

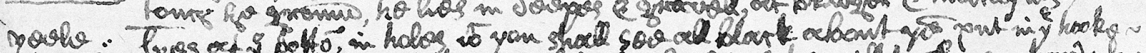

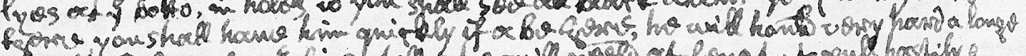

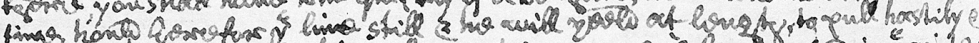

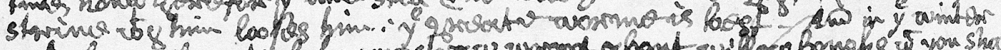

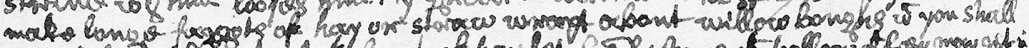

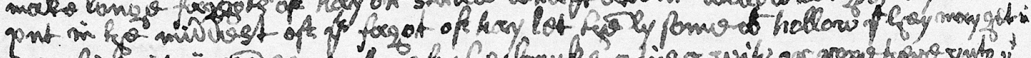

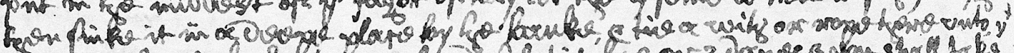

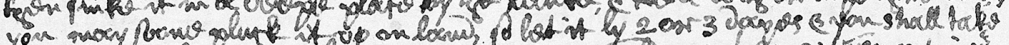

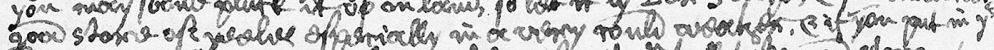

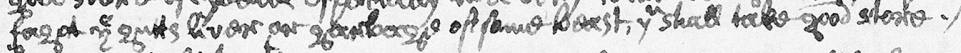

To frowaro y wowns to fish w.

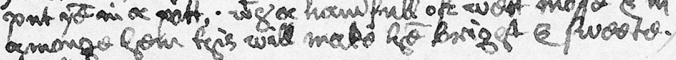

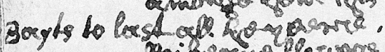

st geverer.

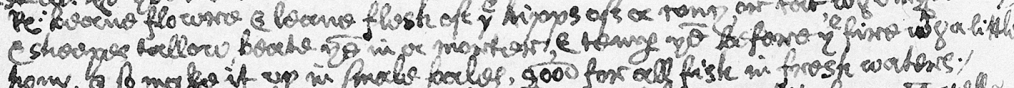

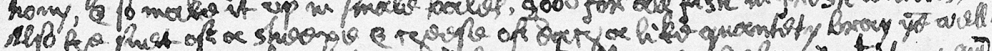

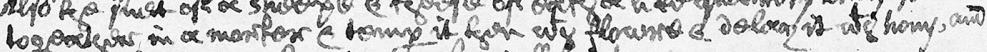

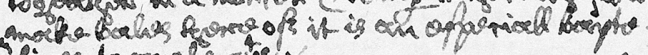

- eclows 2 linos to oxurlo ats.

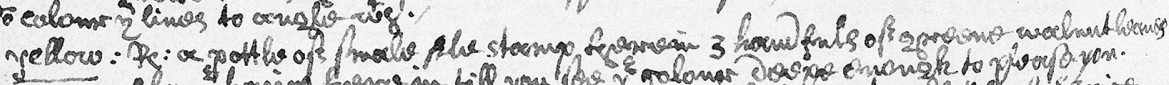

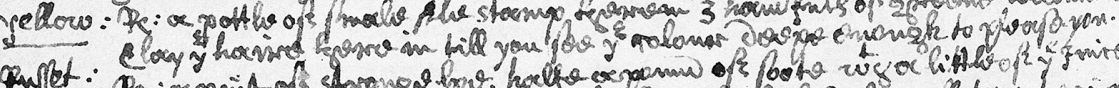

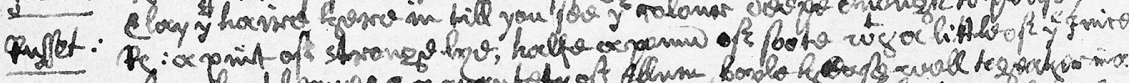

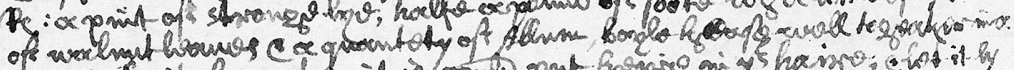

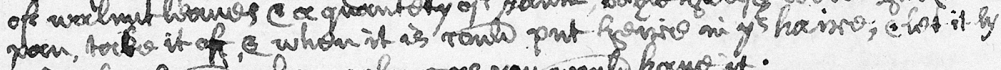

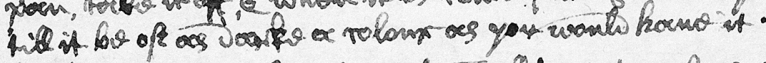

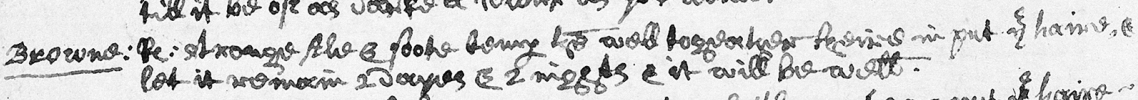

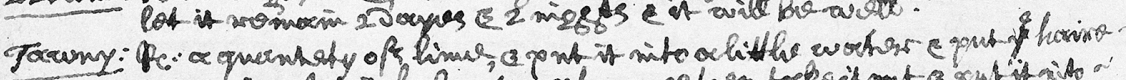

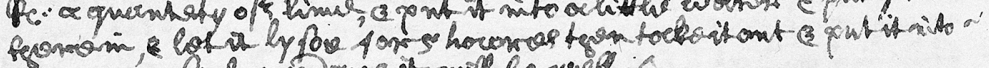

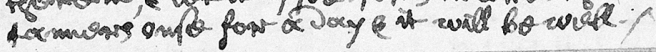

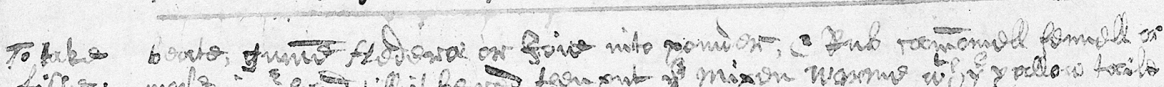

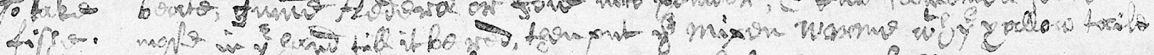

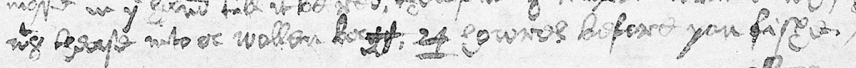

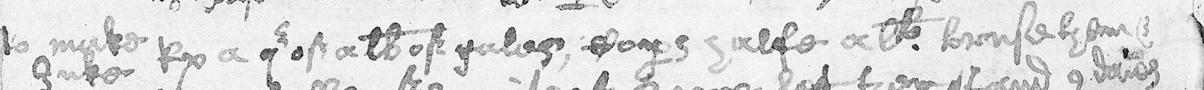

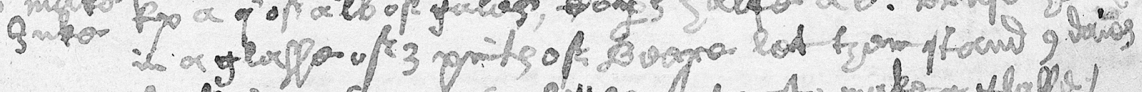

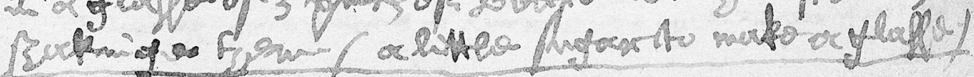

FIGURE 2. Joseph Hall's miscellany, showing Hand A and Hand B. MS V.a.339, Folger Shakespeare Library, fol. 185v. By permission of the Folger Shakespeare Library. 
By establishing the manuscript's organization in advance, Hand A could ensure that material in the same field, copied at different times and in different stints, was gathered together. Material was not entered in this manuscript sequentially-that is, from beginning to end or from the first leaf to the last—but by category or subject. This is evident from variations in ink and nib across the manuscript as a whole. The categories themselves are seven in number and constitute broad divisions of knowledge: (i) theology and divinity; (ii) medicine; (iii) household recipes; (iv) civil discourse and poesy; (v) politics; (vi) figures and rhetoric; and (vii) fables, epigrams, and axioms. ${ }^{18}$ Although Hand A did not write these categories by name in the upper margins of his manuscript, as with commonplace heads, they can be inferred from the consistent way in which he gathered material of a similar kind and the manner in which he recorded his notes. Six of the seven categories begin not, as one might expect, on the recto of a leaf, but on the verso. The only exception is theology and divinity, and since that is the first category, this is perhaps understandable. ${ }^{19}$ Furthermore, within each of the seven categories, the compiler's practice was also consistent. He normally entered his material as a continuous text block, even if he copied it at different times, and gaps between individual items are therefore very rare. Where he did leave space was at the end of each category: presumably in anticipation of material that he might copy in the future.

In addition to devising the seven categories, Hand A also seems to have estimated beforehand the amount of material that he might copy into each. The sections are not equal in length, suggesting that he did not allocate the same number of leaves to each. By far the longest are the first two, to which he allotted 95 and 87 leaves respectively. As it happens, he got his reckoning wrong. In the end, the category that he entered most material in was neither theology and divinity nor medicine, but civil discourse and poesy. Here, among other things, he copied extracts from (and sometimes entire) poems by Richard Corbett (fol. 196r), Ben Jonson (fol. 197v), Thomas Campion (fols. 197v and 198v), Edward Dyer (fol. 204v), and John Donne (fol. 201r). ${ }^{20} \mathrm{He}$ also copied extracts from Shakespeare. These include the whole of Sonnet 138 (fol. 203v), which mostly follows the readings of the first edition of The Passionate Pilgrime (1599), ${ }^{21}$ and five lines from one of King Richard's speeches from Richard II 3.2 (fol. 207v). ${ }^{22}$ Other material that he copied in this section of the manuscript includes

18. Pace Dawson, who in a previous study of the manuscript identified six rather than seven categories; see Dawson, "John Payne Collier's Great Forgery," 3.

19. Hand A's seven categories begin at fols. $3 \mathrm{r}, 96 \mathrm{~V}, 182 \mathrm{~V}, 188 \mathrm{v}, 208 \mathrm{v}, 246 \mathrm{~V}$, and $276 \mathrm{v}$ respectively.

20. The first lines of these poems are "Am I mad o noble Festus" (Catalogue of English Literary Manuscripts, www.celm-ms.org.uk [hereafter CELM], CoR 67.5), "Come my Celia let vs proue" (CELM, JnB 449), "Faine would I wed a fair young man" (CELM, CmT 26), "I must complaine, yet doe enioy my loue" (CELM, CmT 53), "The lowest trees haue tops, $\mathrm{y}^{\mathrm{e}}$ Ant her gale" (CELM, DyE 87), and "Send home my long strayed eyes to me" (CELM, DnJ 2318).

21. CELM, ShW 30. See William Shakespeare, [The Passionate Pilgrime] ([London?, 1599]), fol. [1]r. The most notable exception is line 11: whereas the printed text reads, "O, Loues best habit's in a soothing toung," Hall's miscellany reads, "o loues best<e > habit is a smoothing tongue."

22. CELM, ShW 79; "the worst is worldly losse $\mathrm{y}^{\mathrm{u}}$ canst vnfould / say, is my kingdome lost? whie $\mathrm{y}^{\text {ts }}$ my care, / striues Bullingbrooke to be as greate as me / greater a shall not bee if he serue god / wele serue him too, \& be his equall so." Hand A enclosed these lines with a single brace and then identified their source ("k: R: 2:") in the margin alongside. 
a series of epigrams on moral themes such as "lust," "myrth," "youth," "Experience," "fame," and "Humility" (fols. 205v-7v), four maxims headed "4: of machiviles precepts" (fol. 207v), copied not directly from Machiavelli, but from an allusion to him in Nicholas Breton's 1597 dialogue Wits Trenchmour, ${ }^{23}$ and two further numbered, but untitled, lists of moral precepts (fols. 207v-8r).

Hand $\mathrm{B}$, on the whole, honored the first scribe's categories and made a valiant attempt to follow his model and classify his material in the same way. So in the opening section, after the first compiler's items (fols. $3 \mathrm{r}-25 \mathrm{v}$ ), he entered a much larger tranche of theological material (fols. $25 \mathrm{v}-87 \mathrm{r}$ ). Furthermore, he sought to organize that material, separating the items most closely associated with Hand A's notes from the bulk of what he copied. Much of Hand A's theological material is doctrinal, although he did also copy prayers. His entries include notes on the abrogation of the Sabbath ("De Abrogatione legalis Sabbathi" [fols. $3 \mathrm{r}-5 \mathrm{v}$ ]); notes on the repeal of the laws of Moses in the Christian church, taken in part from the Italian Reformed theologian Hieronymus Zanchius (fols. 5v-6r); a gloss on Thomas Aquinas's account of justification by works (fol. 2or); and a series of five notes of a decidedly anti-Catholic bent ("An absolute Papist cannot be saved," "That the Authority of $\mathrm{y}^{\mathrm{e}}$ Fathers oft not to stand vnlesse it can be warranted out of the word of God," "Against Transubstantiation," "gainst invocation of Saints," and "of Free will" [fols. 22v-23r]). Hand B, by contrast, copied little material of this sort. Instead, first of all, he entered miscellaneous theological notes, which range from biblical commonplaces gathered under the heading "The promises of Christ to all beleeuing Christians" (fol. 26r) to reading notes from John Taylor's Verbum Sempiternum (1616) (fols. 26v-31r) and an extract from Nathaniel Carpenter's Achitophel, or, The Picture of a Wicked Politician (1627), his three sermons against Arminianism preached at St. Mary's, Oxford (fols. 34v-39r). This material he entered immediately after Hand A's notes. Then, however, he switched tack, and after leaving a gap of three leaves, he started to copy material that concerns more practical divinity: primarily prayers and sermon-notes. Given the nature of the manuscript as a whole, in terms of both handwriting and contents, these sermon-notes are unlikely to be first-order notes-that is, notes taken in haste by an actual listener. Nor are they likely to be the skeletons from which a preacher actually delivered his sermons. Instead, they are more likely to be second-order notes, written up after the event. ${ }^{24}$ The fact that Hand B originally left three blank leaves (fols. 39, 40, and 41) between the practical divinity and the earlier doctrinal notes suggests that he may have wanted to distinguish explicitly between the two kinds of material. What the first section of the manuscript therefore suggests is that the second scribe worked within the first scribe's scheme, but also sought to modify that scheme to make its taxonomy even more precise.

23. See Nicholas Breton, Wits Trenchmour, In a conference had betwixt a Scholler and an Angler (London, 1597), sig. D1r-v.

24. For the distinction between first- and second-order notes, see Blair, Too Much, 64-65. For more on the various types of sermon-notes, see Mary Morrissey's essay in this issue. 
The second section in the manuscript gives a similar impression. However, this time, instead of copying his notes on the blank leaves following the notes of Hand A, Hand B gathered his material in the foregoing space (fols. 91v-96r). Furthermore, as with the theological material, there is once again a slight distinction in the kinds of notes that the two scribes took. Whereas Hand A mostly recorded medical recipes and rules, Hand B tended to favor reading notes. These include two sets of extracts from John Read's A Most Excellent and Compendious Method of Curing Woundes in the Head, and in Other Partes of the Body (1588), an English translation of Franciscus Arcaeus's work on surgery, which he headed respectively "Ex Francisco Arceo" (fols. 92v-93r) and "Ex anotationibus Iohanis Reade" (fol. 93r-v), and a batch of notes from Andrea Lacuna's 1553 epitome of Galen, which he headed "Epitomes totius Galleni per Andrea $m$ Lacuna $m$ venetis Editum: in quatuor sectiones digest $u m$ ” (fol. 94r). In addition, he copied a dietary poem, which begins, "To keepe good diett, you should neuer feede" (fol. 91v); a series of verses on Epicurus (fol. 92r); a table of the planetary influences on parts of the body (fol. 92r); a further pair of verses on diet and health ("Ripe $\mathrm{C}^{\wedge} \mathrm{h} \wedge$ erries breede good blood and healps the stone / if Cherry you do eate and Cherry stone" and "to close $\mathrm{y}^{\mathrm{e}}$ stommake, well this order suits / Cheese after fleshe, Nutts after fishes or fruits" (fol. 92r); a note on the epiglottis (fol. 96r); and a short poem on the medicinal qualities of various plants, titled "Sanat Sanctificat et ditat surgere mane" (fol. 96r). Hand A's medical notes, by contrast, are more homogeneous and more obviously grouped together: rules for the maintenance of good health (fols. 97v-98r); notes on the four humors, gathered under the headings "The Description of $\mathrm{y}^{\mathrm{e}} 4$. Complexions," "Complexions of meats ar knowne by theire tasts," "of vrine," and "The signes of the Excrements" (fols. 98v-99v); astrological notes on the propitious times for selecting herbs, under the title "Elections medicinall or phisicall" (fols. 99v-10or); and a long series of recipes for mostly quotidian complaints, ranging from toothache to sore limbs and leaking breasts (fols. 100v-107r).

Sometimes, however, Hand B struggled with the first scribe's classificatory scheme. On occasions the problem was a material one. There was simply not enough space in the appropriate section of the manuscript for what he wanted to copy, as with the two items at folio 95r, an explanation of the four seasons and their origin in man's first disobedience and fall and a note on prophecy, both of which belong more properly with the theological material earlier in the volume, but were recorded here presumably because there was no space left in that section. On other occasions, though, his problem was a more fundamental one: a difficulty with the kind of categorization that the manuscript enacts, with the classificatory scheme itself. Both of these problems are illustrated by a pair of items that Hand B copied at the end of the first section of the manuscript. Neither really concerns theology, and so neither, taxonomically speaking, belongs to this section. The items are fifteen poems, including Sonnet 45 from Samuel Daniel's Delia ("Care-Charmer Sleepe sonne of the sable Night"), ${ }^{25}$ and observations 
on "the Motions of the heavens and heavenly bodies" (fols. 87v-91r). There are various reasons why Hand B might have copied these items here, but exigency of space was doubtless one of them. It certainly explains the presence of the poems. In categorial terms, they would fit more obviously in the fourth section of the manuscript. But Hand A had left very little room there, so perhaps when Hand B went to copy them, he noted them down where he could find enough blank space, and that meant breaking the volume's careful organizational scheme. The observations on the heavens, on the other hand, speak of the more fundamental problem, as there is no category in the manuscript for astronomy. (Despite the presence of the shape poem on the second leaf, Hand A does not seem to have been interested in this kind of material.) Thus when Hand B copied them, he had to make do with one of the existing categories, and of these, the first section, theology and divinity, undoubtedly was the best fit.

\section{宛}

Hall's miscellany is a very elaborate example of the process that Jonathan Gibson has suggestively called "casting off blanks." ${ }^{6}$ Casting off was the process in the early modern printing house whereby the compositor or master calculated the space needed to print by forms rather than seriatim and marked up copy so that type could be set accordingly. ${ }^{27}$ Gibson suggests that manuscript compilers often made a similar calculation, and he defines casting off in this context as "the practice of leaving several pages of a manuscript blank in order to create distinct sections into which to copy an as yet undecided number of texts." 28 For him, therefore, the process was primarily a quantitative one: a calculation based on the amount of material that a compiler might expect to collect. Hall's miscellany suggests that the process could also be a qualitative one. Casting off, that is to say, could be a form of classification: a way of ordering disparate material into groups and also, therefore, a way of organizing knowledge. The miscellany also suggests that, having cast off his or her blanks in this way, and gathered material accordingly, a compiler had a finding device every bit as effective as Oxinden's tabs or Isham's compartments.

The kind of organization found in Hall's miscellany is generic or, as its original compiler would more likely have said, generical. ${ }^{29}$ Although genre today is under-

26. Jonathan Gibson, “Casting Off Blanks: Hidden Structures in Early Modern Paper Books," in Material Readings of Early Modern Culture: Texts and Social Practices, 1580-1730, ed. James Daybell and Peter Hinds (Basingstoke, U.K., 2010), 208-28. See also Harold Love, Scribal Publication in Seventeenth-Century England (Oxford, 1993), 117-18, 129, and the discussion of casting off blanks in Michelle O'Callaghan's essay in this issue.

27. See Philip Gaskell, A New Introduction to Bibliography (New Castle, Del., 1995), 41-42.

28. Gibson, "Casting Off Blanks," 208.

29. According to the $O E D$, the word generic was not coined until 1658; the earliest citation that it gives for generical, by contrast, is John Trevisa's fourteenth-century translation of Ranulf Higden's Polychronicon. 
stood almost always in a literary or artistic sense, that was not the case in the early modern period. As Rosalie Colie put it forty years ago, generic distinction at that time "extended beyond officially poetic forms to grant a principle of kind to all and any writing." 30 The early moderns understood generic categories as large groups or classes, as types rather than individual objects or specific phenomena, a distinction that is nicely illustrated by Nehemiah Grew's description of one of the fossils in the collections of the Royal Society in his 1685 catalogue of them: "The Black BELEMNITES. The generick Name is from the shape, like that of a Bolt-head. This Species is outwardly of an ash-colour, but black within: and therefore by some called Coraceas." 31 Although Grew's catalogue postdates Hall's miscellany by some forty years, the distinction between generic and specific did exist earlier in the century. In 1648, for example, Nicholas Bernard made the same distinction in his Christmas sermon The Still-Borne Nativitie, as he glossed John 1:29 ("Behold the Lamb of God, which taketh away the sin of the world") and explicated reasons for the incarnation of Christ:

Which sinne of the World reading it in the singular number: Bede interprets original sinne. Because that alone of all other, is the sinne of the whole world, And indeed taken extensively is without comparison the greatest sinne that ever was: no one actuall beside being to be charg'd upon all men [...] But I conceive the word sinne is rather Genericall then Specificall containing as well actual as original, For proofe whereof I oppose St Peter Comment. Act. 3. 26, to that of Bede.32

Hand A makes a parallel distinction in the organization of his manuscript. His seven categories are generic divisions of knowledge; the individual items that he copied are the specifics that make up those groups.

In the manuscript itself, this distinction between generic and specific also has a perceptible material or spatial dimension. Although Hand A did not write his categories in the upper margins in the manner of commonplace heads, he did often write

3o. Rosalie L. Colie, The Resources of Kind: Genre-Theory in the Renaissance (Berkeley, Calif., 1973), 16. For a more recent iteration of the importance of generic markers in the early modern period, and an argument that suggests that they served as indications not only of content but also of attitudes toward that content, see Ceri Sullivan, "Disposable Elements? Indications of Genre in Early Modern Titles," Modern Language Review 102 (2007): 641-53.

31. Nehemiah Grew, Musaeum Regalis Societatis: or, A Catalogue and Description of the Natural and Artificial Rarities Belonging to the Royal Society, and Preserued at Gresham Colledge (London, 1685), 302.

32. The Still-Borne Nativitie: or, A Copy of an Incarnation Sermon, that should have been delivered at St. Margarets-Westminster, on Saturday, December the five and twenty, 1647. in the afternoone, by N. B. but Prevented by the Committee for Plunder'd Ministers who sent and seized the Preacher, carried him from the Vestry of the said Church, and Committed him to the Fleet, for his undertaking to Preach without the Licence of Parliament (London, 1648), sig. D3r. 
subdivisions or headings for his entries horizontally in the left-hand margins, something that figure 2 again illustrates. The twelve headings that he wrote on this page (fol. 185v) all relate to the subject of angling, and together they represent a subdivision of Hand A's third generic category (household recipes). They therefore correspond with the specifics in Grew's taxonomy and Bernard's Christmas sermon. Moreover, their arrangement also constitutes a hierarchy of knowledge, as their disposition on the page is far from random. There is a clear progression in the headings, as they begin with kinds of fish ("Roch," "Dace," "Bleke, alias Bley," "Googing” [gudgeon], "Yeele”), before moving on to bait ("To scowre $\mathrm{y}^{\mathrm{e}}$ wormes to fish $\mathrm{w}^{\text {th" }}$ and "Bayts to last all the yeere"), and then finally to fishing lines ("To colour $\mathrm{y}^{\mathrm{e}}$ lines to angle $\mathrm{w}^{\text {th }}$," "Yellow," "Russet," "Browne," “Tawny"). Thus not only do the seven categories constitute a strategy for search and retrieval, but the specific headings within those generic categories further organize the notes to make the retrieval of individual items, in particular pieces of practical information such as here, even more straightforward. What enabled Hand A to do this was his mise-en-page: not the vertical layout found in humanist commonplace books, but the horizontal orientation that was increasingly common in other kinds of manuscript books.

Hand A's generic organization of the manuscript focuses on res rather than $v e r b a$, and it is oriented toward fields of knowledge rather than individual words or rhetorical topics. As such, the manuscript corresponds exactly with Francis Bacon's vision in Of the Proficience and Advancement of Learning (1605) of a new kind of commonplace book that carries not only "the face of a Schoole," but also "of a World."33 Whence Hand A took his inspiration for this generic organization is a matter of conjecture, but he would have had a number of possible models, since comparable systems of classification existed in a range of textual practices. Booksellers' catalogues, for example, were usually organized in a similar way. 34 So too were library catalogues, which, until the middle of the seventeenth century and the advent of alphabetization, were usually arranged by genre or subject. ${ }^{35}$ Initially, library subject catalogues followed the medieval pattern of arranging books according to the four faculties of theology, medicine, law, and arts or philosophy. However, by the beginning of the seventeenth century, more specific catalogues started to emerge, dividing books into further categories and other fields of knowledge. This occurs in both the 1574 catalogue of Archbishop Parker's gift to Corpus Christi College, Cambridge, which divided the books therein into Theologica, Historica, Iuridica, Medica, Philosophica, Ethica, Physica, Metaphysica, Mathematica, and Poetica, and the individual subject

33. The Oxford Francis Bacon, vol. 4, The Advancement of Learning, ed. Michael Kiernan (Oxford, 2000), 118 (sig. 2P2r).

34. Colie, Resources, 15-16.

35. For overviews of library organization in the Renaissance, see Sears Jayne, Library Catalogues of the English Renaissance (Berkeley, Calif., 1956), 29-39; and Dorothy May Norris, A History of Cataloguing and Cataloguing Methods 1100-1850: With an Introductory Survey of Ancient Times (London, 1939), 126-80. I am extremely grateful to Dr. András Kiséry for drawing my attention to the importance of library catalogues as a possible model for Hall's miscellany. 
catalogues for the Bodleian Library that Thomas James started to compile from 1607.36 Although the books themselves were arranged in the Bodleian's chained bookcases according to the faculty model, James's subject catalogues opened up many more fields of knowledge, including subjects such as the military arts, politics, and architecture, which did not form part of the university curriculum. In another suggestive parallel with Hall's miscellany, James compiled his subject catalogues as a strategy for search and retrieval - that is, as a means to enable students to find books on a given subject more easily than by following their classified order on the library's shelves.

Hand A's arrangement of his notes also corresponds with the organization of other early modern manuscript books. The allocation of various parts of a single manuscript to various subjects was common throughout the seventeenth century. This is most obvious in the phenomenon of the reversed manuscript-that is, a manuscript written in from both ends. One of the main reasons compilers reversed manuscripts in this way was to differentiate between kinds of text or note: something clearly seen in the miscellany kept by Thomas Medcalf in the first half of the century. 37 Medcalf entered commonplaces in Latin, English, and Greek under alphabetically organized heads at one end, and poems, political news, and items relating to the court at the other. Another common reason for compilers to reverse manuscripts was to separate accounts, reckonings, and financial records from other kinds of entry or note. Charles Leche, for example, a merchant from Chester, did this in the memoranda book that he kept between 1606 and $1643 .{ }^{38}$ At one end he and his scribes entered records of sales, inventories, and accounts; at the other they copied more miscellaneous notes, ranging from recipes for sick hawks (fols. [1] r-[9]v rev.) to antiquarian notes on the history of Chester extracted from William Aldersey's "A Collection of the Mayors Who Governed the Cittie of Chester with the Antiquities of the Same" (fols. [12]v-[32]v rev.). Financial records, of course, needed not only to be organized in themselves, but also to be easily retrievable. Reversing a manuscript that contained this kind of material was therefore another strategy for search and retrieval, another way in which a compiler could use the spatial disposition of his or her notes to organize them.

Hall's miscellany exhibits the same principle, albeit extended so that it classifies not only two kinds of material, but also knowledge much more broadly. Thus, despite the meticulousness of its classification and the consequent complexity of its structure, Hall's miscellany is still a representative manuscript. In fact, in some ways its complexity makes it a particularly useful typological case study, for beyond its chaotic exterior, its underlying principle is readily apparent. This miscellany, that is to say, compellingly illustrates how compilers deployed the resources of mise-en-page not only to organize material as they read or otherwise encountered it, but also in anticipation of its future

36. For Parker's gift, see Jayne, Library Catalogues, 34. For James's subject catalogues, see G. W. Wheeler, The Earliest Catalogues of the Bodleian Library (Oxford, 1928), 94-116; and Ian Philip, The Bodleian Library in the Seventeenth and Eighteenth Centuries (Oxford, 1983), 14.

37. Folger, MS V.a.130.

38. DLE 85, Cheshire Archives and Local Studies, Chester. 
use, whether for practical, doctrinal, or aesthetic reasons. In combining notes on how to catch river fish with theological material and extracts from Shakespeare, this manuscript covers all three bases. Furthermore, its fundamental organizational schemethe division of paper and space and the physical separation of categories-is entirely typical of early modern miscellanies. Indeed, by the beginning of the seventeenth century, this organizational scheme, the early modern equivalent of file dividers, had become perhaps the most widespread and common strategy for the search and retrieval of handwritten notes.

Unlike with file dividers, however, Hall's miscellany does not have an immediately discernible, external sign of organization. The strategy for search and retrieval is, instead, undeclared and, to the unwary scholar, unseen. But that is perhaps the point: this manuscript was, first and foremost, a personal compilation, put together probably by one individual (Hand A) and continued by another (Hand B). What was readily apparent to them did not therefore need to be immediately visible to others. The strategy for search and retrieval is not exactly hidden; it is just that it is not explicit or explained. Here, then, is an important difference between the information management of early modern print culture and the manuscript equivalents described in this essay. Whereas the former emerged out of a growing awareness of readers' needs, the latter were primarily driven by the needs of their compilers. The strategies associated with the former were therefore inevitably (and necessarily) more explicit than many of those connected with the latter. This explains, for instance, why manuscript miscellanies do not always contain alphabetical indexes, one of the fundamental developments of information management in print culture, and it also perhaps explains why, when indexes are found, they are often in the hand not of the original scribe but of a later owner. 39 Nonetheless, as the example of Hall's miscellany demonstrates, information management was still vitally important for manuscript culture. Compilers of manuscript miscellanies did often think carefully about the disposition of their material and about the strategies that they would use to organize that material and then to retrieve it. The fact that those strategies are now often out of sight does not mean that to their original compilers they were ever out of mind. Hall's (unexpectedly) well-organized miscellany is again the proof of that.

I should like to thank the Folger Shakespeare Library for awarding me a short-term fellowship in 2010-11, which enabled me to undertake the initial research for this essay. I should also like to thank András Kiséry, Tom Lockwood, and Elizabeth Elliott for comments on previous drafts.

39. See, for example, Agnes Bowyer's miscellany (MS Plimpton 276, Columbia University Library). The index and list of contents ("Thinges mencioned in this booke in order as they are herein written the xxviijth of August. A ${ }^{\circ} \mathbf{1 5 8 9}$ " [fol. 2r-v]) are not in Bowyer's hand, or even in the hand of one of the other early scribes, but in that of an unnamed later owner. 
ANGUS VINE is a lecturer in early modern literature at the University of Stirling. He is the author of In Defiance of Time: Antiquarian Writing in Early Modern England (2010) and Miscellaneous Order: Manuscript Culture and the Early Modern Organization of Knowledge, forthcoming from Oxford University Press.

With Richard Serjeantson, he is coediting volume 3 of The Oxford Francis Bacon, Earlier Jacobean Writings, 1603-1613. He is also editing Thomas Traherne's Early Notebook for volume 4 of The Oxford Traherne. 
